\title{
Dynamic Modelling of a Solar Water Pumping System with Energy Storage
}

\author{
Shatadru Biswas $(\mathbb{D}$ and $M$. Tariq Iqbal \\ Department of Electrical \& Computer Engineering, Faculty of Engineering \& Applied Science, \\ Memorial University of Newfoundland, St. John's, NL, Canada
}

Correspondence should be addressed to Shatadru Biswas; sbb278@mun.ca

Received 19 October 2017; Revised 4 December 2017; Accepted 17 December 2017; Published 8 April 2018

Academic Editor: Sundaram Senthilarasu

Copyright (C) 2018 Shatadru Biswas and M. Tariq Iqbal. This is an open access article distributed under the Creative Commons Attribution License, which permits unrestricted use, distribution, and reproduction in any medium, provided the original work is properly cited.

\begin{abstract}
This paper describes the dynamic modelling of a system used for extraction of groundwater for irrigation using an alternative source of energy. The system is designed based on data of an existing project in Lalmonirhat, Bangladesh. The system comprises a $38.4 \mathrm{kWp}$ solar photovoltaic array, inverter, AC motor, and pump set, which can discharge a maximum of $1,930 \mathrm{~m}^{3}$ of water per day. MATLAB simulation is performed with two types of energy storage system: (i) electric energy using a battery bank and (ii) stored water in a large water tank. A large battery bank and a transformer are needed in the former one, which turns out as a costly solution. The latter one requires a boost converter and a large water tank to store around $2,000 \mathrm{~m}^{3}$ of water, which is also a costly solution. A combination of both systems yields an efficient and economical solution. The effectiveness of these three systems is compared with conventional diesel engine system.
\end{abstract}

\section{Introduction}

Bangladesh is an agriculture-based, densely populated developing country and its 35 percent of GDP comes from agriculture sector [1]. Around 59 percent of cultivable land needs irrigation because monsoon based cultivation cannot meet the challenges as described by Khan et al. 2014 [2]. Irrigation is needed to produce rice, the main crop of Bangladesh, during the dry season (January to May). Above 85 percent of the cultivable land is under ground water irrigation system; the rest is under surface water irrigation system [3]. Generally electric power (where available) and diesel engine (in offgrid areas) are used for irrigation. Moreover, only 53 percent of the population has access to electricity. There are 1.71 million pumps in Bangladesh: 83\% diesel operated and 17\% electrically operated [3]. Bangladesh has to import billions of liters of diesel to run these pumps. In this situation, solar irrigation pumps may be an alternative for irrigation in the off-grid areas. Bangladesh is blessed with enormous solar resources because of geographical location (Figure 1). It is situated between $20.30^{\circ}$ and $26.38^{\circ} \mathrm{N}$ and $88.04^{\circ}$ and $92.44^{\circ} \mathrm{E}$, with an average solar radiation of 4.0 to $6.5 \mathrm{kWh} / \mathrm{m}^{2} /$ day and in bright sunshine 6.0 to $9.0 \mathrm{KWh} / \mathrm{m}^{2} /$ day [4].

Hossain et al. 2015 [5] stated that, according to the baseline survey, only 150 solar pumps existed in Bangladesh in 2010. Among them, 65\% pumps were used for supplying drinking water and only $35 \%$ were used for irrigation purpose. They also stated that in Bangladesh small scale solar pumping system is available which ranges from $300 \mathrm{Wp}$ to $1190 \mathrm{Wp}$ and discharge capacity was 2000 to $80,000 \mathrm{~L} / \mathrm{d}$. They addressed the main problem that, in Bangladesh, panel cost was the major cost (45\%) in solar irrigation system followed by installation (18\%), motor (16\%), pump (10\%), and pipes and fittings (4\%). Moreover, PV pumping system requires high capital cost, water storage for cloudy weather, and skilled personnel, as mentioned by Abu-Aligah 2011 [6].

Arrouf and Ghabrour 2007 [7] used buck-boost converter in the Simulink model for smooth operation. Malla et al. [8] designed a battery-less PV system in MATLAB/Simulink and described the control strategies. They adopted MPPT 


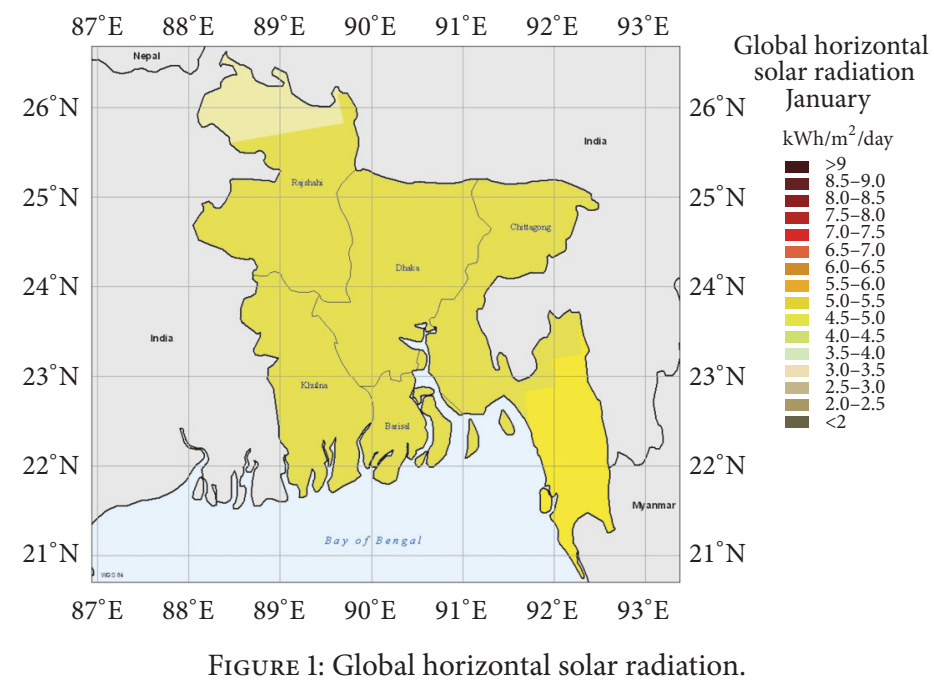

(Maximum Power point tracker) in their system. This paper represents dynamic simulation of battery-based and batteryless solar water pumping system for irrigation.

According to Arrouf and Ghabrour 2007 [7], the technology of solar cell is growing fast. Gopal et al. 2013 [9] stated that solar photovoltaic water pumping systems are the most widely used renewable energy source water pumping system for irrigation and domestic use. Abu-Aligah 2011 [6] also stated some advantages of solar PV system: unattended operation, low maintenance, easy installation, and long life. In this situation the Government of Bangladesh is promoting alternative sources of energy to meet the energy deficiency. Many governmental and nongovernmental organizations are encouraging people to go with renewable sources of energy. Bangladesh Government is giving subsidies for alternative energy projects. Many solar irrigation pumping system sites exist in Bangladesh.

A lot of organizations are coming forward to finance large renewable energy projects. Grameen Shakti is one of the nongovernmental organizations which has installed a large solar irrigation pumping system (SIPS) to irrigate a considerable land area in Bangladesh. Sherpa Power Engineering Limited provides the technical support. The project name is Grameen Shakti-Gorol or GS-Gorol project which is situated in Gorol (Kamlartari), Kaligonj, Lalmonirhat, Bangladesh $\left(26^{\circ} \mathrm{N}, 89.28^{\circ} \mathrm{E}\right)$. The dynamic modelling of a solar irrigation pumping system with storage is performed based on this reference site.

The main objective of this paper is to look at the expected variation in the bus voltage and pump speed after a dipin solar radiation and temperature. This paper will also try to achieve an optimum solution between battery-based and battery-less solar irrigation pumping system.

\section{Literature Review}

Loxsom and Durongkaveroj 1994 [10] developed an algorithm to estimate the monthly water discharge of a batteryless PV water pumping system using nonlinear relation between the pumping rate and insolation. This algorithm reduces the amount of computation which was required for hourly simulation. The algorithm could estimate the annual performance of a PV pumping system within $2 \%-4 \%$ of the result. Cuadros et al. 2004 [11] proposed a computer program to design a PV installation for irrigation which consists of three stages, that is, irrigation requirement, hydraulic analysis, and PV power requirement. Their aim was to introduce a design procedure that considers the above criteria before any PV pumping installation. Glasnovic and Margeta 2007 [12] developed a mathematical model to acquire an optimal PV system by considering not only water demand or irradiance but also including natural process, that is, climate, hydrology, boreholes, pumping system, irrigation, agriculture, and power supply. The system used dynamic programming to achieve optimal size. Arrouf and Ghabrour 2007 [7] modelled and simulated a pumping system fed by a PV generator in MATLAB/Simulink. The system included PV generator, DCDC converter, DC-AC converter, asynchronous machine, and centrifugal pump. They simulated each part of the system separately under specific condition and the result satisfied their expected values. Gad 2009 [13] proposed a computer simulation program to predict the performance of a PVDC system using solar irradiance data for three different tilt positions all over the year. The calculated PV array efficiency ranged from $13.86 \%$ (winter) to $13.91 \%$ (summer) which is larger than the specified efficiency (13\%) by tender. Malla et al. 2011 [8] designed a stand-alone PV water pumping system without battery storage in MATLAB/Simulink. The system consists of Perturb and Observe (P\&O) algorithm based MPPT (Maximum Power Point Tracker) for improving efficiency. He described the control strategy to regulate the water discharge for a single induction motor as well as multiinduction motor. Harishankar et al. 2014 [14] proposed a controlled irrigation system in which the outlet valve of the tank was automatically regulated using controller and moisture sensor to control the flow rate of the water from the tank to the irrigation field to optimize the use of water.

Anis and Nour 1994 [15] designed a PV powered pumping system based on switched-mode operating system. He also analyzed the interdependence of the system 
parameter. According to Chandel et al. [16] DC or AC submersible/surface mounted/floating motor-pump sets are suitable solar PV pumping system. Argaw [17] concluded that $\mathrm{PV}$ arrays can be configured from V-I characteristic of a single cell and required rated power for the motor/pump. Pande et al. 2003 [18] proposed a PV water pumping model to ensure uniform irrigation in arid regions using Openable Low Pressure Compensating (OLPC) drippers and manual tracking. Abu-Aligah 2011 [6] designed a direct coupled, battery-based, grid connected photovoltaic system. Benghanem et al. 2013 [19] studied the performance among four different PV array configurations for a deep well using helical pump. Two of them gave the optimum energy to lift water. Senol 2012 [20] studied small and medium size mobile solar PV power station for drip irrigation. He considered two different scenarios: (i) PV station used by a single farmer with maximum discharge of $18 \mathrm{~m}^{3} / \mathrm{d}$ and it had water storage and (ii) PV station used by four farmers with maximum water discharge of $52 \mathrm{~m}^{3} / \mathrm{d}$ and it had no water storage. Abul Hasnat et al. 2014 [21] proposed a hybrid solar irrigation. The pump was fed by bot solar PV array and grid electricity.

According to Anis and Nour [15] increasing the water tank size is more economical than increasing both array and battery size. Hoque [22] concluded that for consecutive three seasons' irrigations, the unit cost of water is cheaper in case of PV water pumping system comparing with diesel engine system. Abu-Aligah 2011 [6] did the cost and reliability analysis between PVDC and diesel engine system and PVDC system turned out as more reliable system. He also did the Life Cycle Cost (LCC) analysis for a period of twenty years and found that the solar energy system was cheaper although the initial cost was high for it. Senol 2012 [20] performed economic analysis for three different cases: (i) no subsidy, (ii) 50\% subsidy (not including PV module cost), and (iii) 50\% subsidy (including PV module cost). The investigation proved that PV powered pump is preferable. Abul Hasnat et al. 2014 [21] concluded that hybrid solar irrigation was more feasible than solar irrigation project as payback period decreases about five to seven years. According to him, before five years of operation, LCC is lower for diesel engine, but it became lower for solar PV pump after five years of operation. He also suggested that investment in solar pump is more profitable and risk free than diesel engine operated irrigation system.

Hamidat and Benyoucef 2008 [23] found that DC engine with a positive displacement pump is more efficient and discharges more water than $\mathrm{AC}$ engine with a centrifugal pump for a wide range of total dynamic head. Mokeddem et al. 2011 [24] monitored the performance of a small direct coupled DC photovoltaic water pumping system at different test conditions by varying irradiance and operating voltage for two different static heads. He found that the system is suitable for low delivery flow rate application. Katan et al. [25] showed that the performance of a PVDC system could be increased by using MPPT and Sun tracker. Khan et al. [26] suggested that using a buck converter would ensure the smooth operation but not increase the cost of the system.
Abu-Aligah 2011 [6] compared the effectiveness between solar PV and diesel engine system. Abul Hasnat et al. 2014 [21] found that operating time increased and idle time decreased for a hybrid irrigation system.

A comparison of energy storage methods and detail dynamic modelling of solar water pumping system is missing in literature. We present detailed analysis of battery-based and battery-less systems and expected transients in a system using MATLAB/Simulink dynamic simulations.

\section{Methodology}

The aim of this paper is to observe the response in pump speed and bus voltage with the change in irradiance and temperature. For this purpose, dynamic model of solar irrigation pumping system with energy storage was built in MATLAB/Simulink environment. A solar irrigation pumping system consists of solar Photo Voltaic (PV) array, inverter, motor-pump set, and storage system. A photovoltaic (PV) module is the assembly of a number of electrically connected solar cells which are mounted on a frame whereas an array can be formed by wiring multiple modules together. PV modules produce direct-current (DC) electricity and any required voltage and current combination is possible by connecting them in both series and parallel electrical arrangements. A solar inverter or PV inverter is an important component of a PV system which converts the variable DC output of a PV solar panel into utility frequency alternating current (AC current). The AC power is used to run a motorpump set ground water extraction. The motor and pump are connected through a shaft. Then the water is stored in a tank for irrigation purpose. There are two types of storage system; energy storage in batteries and water storage in large tank. As PV panel does not work at night and efficiency becomes lesser during cloudy weather, the storage system is designed for one- or two-day back-up. System sizing was carried out by HOMER (Hybrid Optimization and Multiple Energy Recourses) as well as hand calculation. Dynamic model of the system was designed in MATLAB Simulink (MATLABR2016b) on the basis of HOMER optimization result. The PV array gets the irradiance and temperature values from a signal builder. Here, in this paper, two different dynamic models are demonstrated using different storage system types: battery-less system and battery-based system. The irradiance and temperature data are selected in such a way that both will drop for a fraction of second due to clouds and become the same as before when clouds move away. For battery-less system, a boost converter is needed to increase the voltage level. The system will be able to store water in a large tank for one-day usage. The battery-based system consists of a small transformer instead of a boost converter to increase the voltage level and a MPPT for better performance. This paper proposes a solar irrigation pumping system with both battery storage and water tank. Feasibility analysis among these three and the diesel operated engine would reveal the best solution. Sensitivity analysis would investigate how the costs vary along with change in load demand and irradiance. 
TABLE 1: System component.

\begin{tabular}{lc}
\hline System component & Rating \\
\hline PV $[\mathrm{kW}]$ & $38.4(310$ Wp each $)$ \\
Battery storage $[\mathrm{No}]$ & $60(12 \mathrm{~V}, 200$ Ahr each $)$ \\
Inverter $[\mathrm{kW}]$ & 20.7 \\
\hline
\end{tabular}

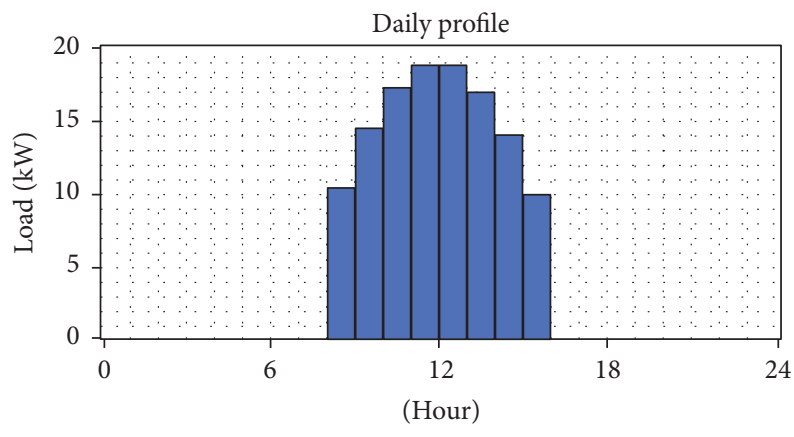

FIGURE 2: Daily load data.

\section{Sizing Using HOMER}

Sizing estimation for the system was done using HOMER (Hybrid Optimization and Multiple Energy Recourses). Daily load data was calculated from the site data of the selected project (Figure 2).

Figures 3(a) and 3(b) show the selected solar irradiance and temperature data for the selected site.

The feasible combination from HOMER optimization is stated in Table 1.

Total Net Present Cost (NPC) of the system calculated by HOMER is $\$ 156.773$. The levelized Cost of Operation (COE) is $\$ 0.442 / \mathrm{kWh}$ and total operating cost is $\$ 4,245 / \mathrm{yr}$. The economic cost breakdown is shown in Table 2 and Figure 4.

As June to September is the rainy season in Bangladesh, the recorded solar irradiance becomes lower in these months.

So, the produced electricity would be lower in these months. Figure 5 shows the monthly average electric production of the system.

The system can produce total $52,804 \mathrm{kWh}$ energy per year and the AC primary load consumption is $100 \%$ $(39,110 \mathrm{kWh} / \mathrm{yr})$. The excess electricity is around $15.2 \%$ $(8,043 \mathrm{kWh} / \mathrm{yr})$.

The PV output ranges from $7.2 \mathrm{~kW}$ to $28.8 \mathrm{~kW}$ mostly during the run time. Although the rated capacity is $38.4 \mathrm{~kW}$, the mean output is about $145 \mathrm{kWh} / \mathrm{d}$ with the capacity factor of $15.7 \%$. If $310 \mathrm{Wp}$ panel is used in the system, total number of panels becomes 124. Figure 6 will give a clear idea about the PV output.

Minimum state of charge for the battery storage was decided as $40 \%$. The frequency histogram in Figure 7 shows that the frequency of being $100 \%$ state of charge is around $40 \%$ and the monthly statistics in Figure 8 implies that the state of charge remains lower in the months from June to September.

A $20.7 \mathrm{~kW}$ inverter was selected to convert the DC photovoltaic output into AC unit. The mean average output of the inverter was $4.5 \mathrm{~kW}$ with capacity factor of $21.6 \%$. The inverter output is shown in Figure 9.

\section{System Sizing}

The system was designed to lift maximum of $1930 \mathrm{~m}^{3}$ of water per day (in the month of October) with average discharge of $241.25 \mathrm{~m}^{3} / \mathrm{h}$.

5.1. Estimation of Total Dynamic Head (THD). Figure 10 demonstrates a water tank based solar water pumping system.

From Figure 10, Elevation Head $=(12+3) \mathrm{m}=15 \mathrm{~m}$.

Friction head loss: the system is using 8-inch $(0.2 \mathrm{~m})$ diameter pipe to supply around 1700,000 liters water per day. The system has three standard elbows and a gate valve. So, the friction head loss for fitting will be $(1.6+0.11)=1.71 \mathrm{~m}$.

Frictional head loss for pipe, using Hazen-Williams Formula is $(0.28+0.16) \mathrm{m}=0.44 \mathrm{~m}$.

Total frictional head loss $=(1.71+0.44) \mathrm{m}=2.15 \mathrm{~m}$.

We can conclude that total dynamic head = Elevation Head + Friction Head Loss $=15+2.15=17.15 \mathrm{~m}$.

5.2. Pump Size. The needed hydraulic power of the pump is

$$
\begin{aligned}
P_{h} & =\frac{Q \rho g h}{3600 \times 1000}=\frac{241.25 \times 1000 \times 9.8 \times 17.15}{3600 \times 1000} \\
& =11.26 \mathrm{~kW},
\end{aligned}
$$

where $Q$ is volumetric flow of water through the pump $\left(241.25 \mathrm{~m}^{3} / \mathrm{h}\right), \rho$ is water density $\left(1000 \mathrm{~kg} / \mathrm{m}^{3}\right), g$ is gravity $\left(9.81 \mathrm{~m} / \mathrm{s}^{2}\right), h$ is total head of the liquid $(17.15 \mathrm{~m})$.

5.3. Motor Size. The induction motor power is

$$
P_{m}=\frac{P_{h}}{n_{m}}=\frac{11.26}{0.75}=15.013 \mathrm{~kW} .
$$

Induction motor-pump efficiency, $n_{m}$, is assumed as $75 \%$.

5.4. PV Panel. The system is designed to run for only eight hours during day time (8 a.m. -4 p.m.).

Pump use $=(15013 \times 8)=120,104 \mathrm{Wh} /$ day.

To estimate the needed PV energy, total watt hour per day is multiplied by 1.3 (system loss) and divided by panel generation factor (4.32 for India).

$$
\begin{aligned}
& \text { PV energy needed }=(120,104 \times 1.3)=156,135.2 \mathrm{Wh} / \\
& \text { day. } \\
& \text { Total Watt power of PV }=(156,135.2 / 4.32)=36,142.407 \\
& \text { Wp. }
\end{aligned}
$$

We are using $310 \mathrm{Wp}$ module.

$$
\text { Number of PV panels }=(36,142.407 / 310) \approx 116.59 \text {. }
$$

The selected panel is 72 cell panels and number of panels connected in series in each string is two. As a result, the bus voltage is $48 \mathrm{~V}$.

$$
\text { Number of strings } \approx 59 .
$$

5.5. Inverter. The inverter capacity is selected as $21 \mathrm{~kW}(40 \%$ bigger than the motor size). 
TABLE 2: Economic cost breakdown.

\begin{tabular}{lccccc}
\hline Component & Capital (US\$) & Replacement (US\$) & O\&M (US\$) & Salvage (US\$) & Total (\$) \\
\hline PV & 55,242 & 4,977 & 1,876 & $-2,318$ & 59,777 \\
Battery storage & 42,000 & 21,513 & 0 & -554 & 62,960 \\
Inverter & 14,003 & 3,193 & 1,174 & -410 & 17,959 \\
Other & 7,000 & 0 & 9,077 & 0 & 16,077 \\
System & 118,245 & 29,683 & 12,127 & $-3,282$ & $\mathbf{1 5 6 , 7 7 3}$ \\
\hline
\end{tabular}

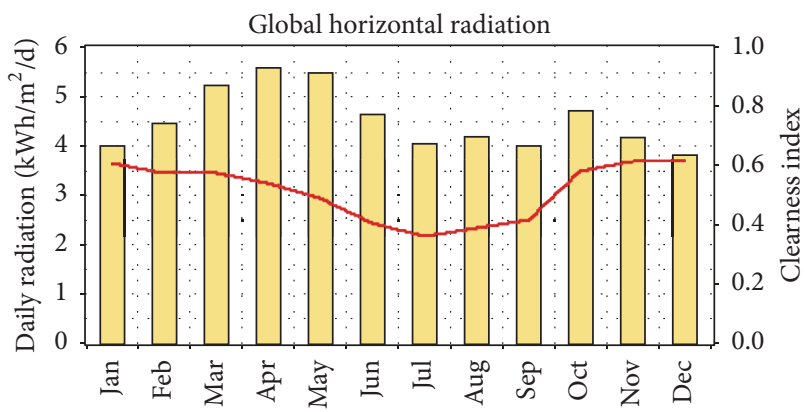

Daily radiation

_ Clearness index

(a)

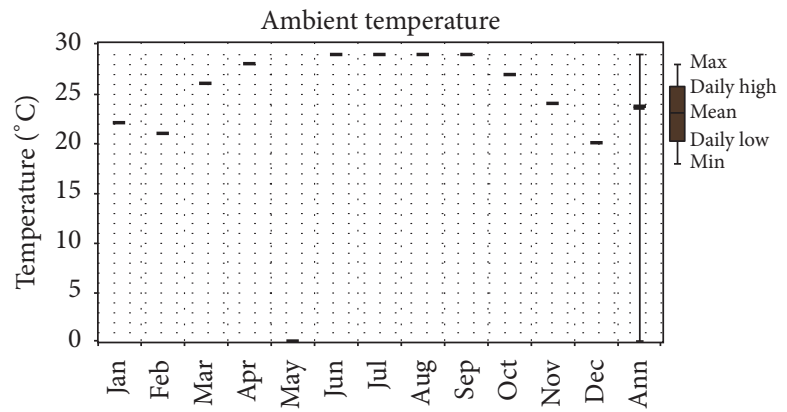

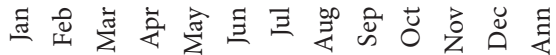

(b)

FIGURE 3: (a) Irradiance; (b) temperature.

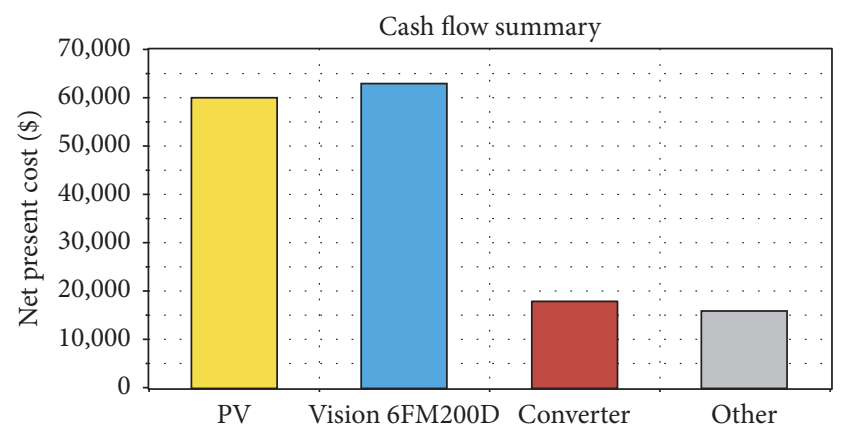

FIgURE 4: Economic cost breakdown.

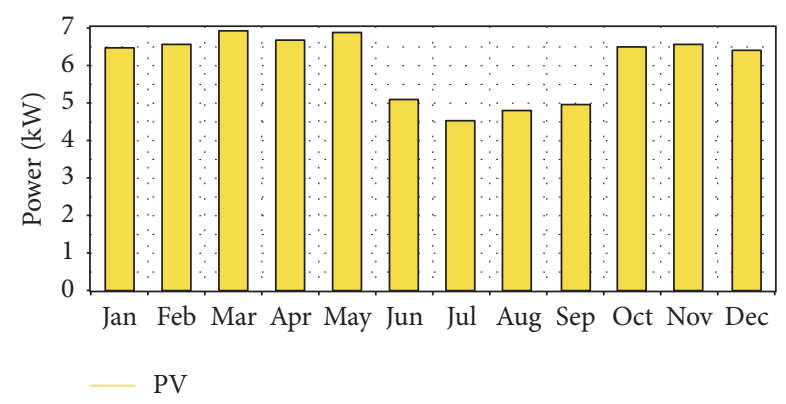

FIGURE 5: Monthly average electric production.

5.6. Battery Storage. For one-day back-up, needed battery bank ampere hour $=(120,104 / 48)=2502.17 \mathrm{Ahr}$.

Battery bank rated capacity is $2600 \mathrm{Ahr}$ and nominal voltage is $48 \mathrm{~V}$.
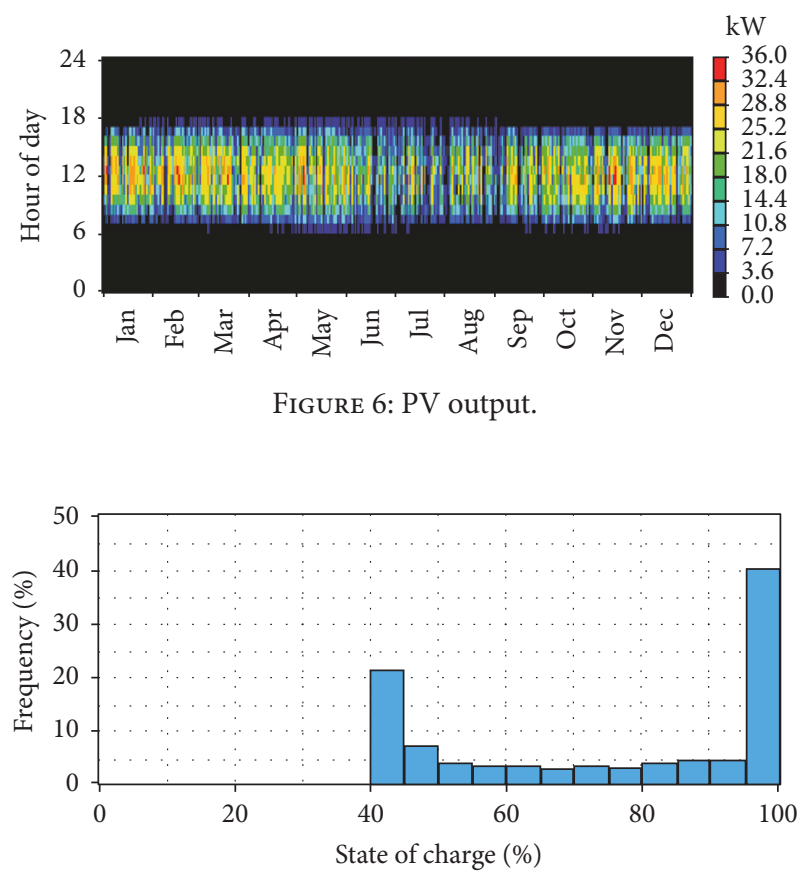

FIGURE 7: Frequency histogram.

\subsection{Water Storage Tank Equivalent to Battery Storage}

From HOMER, number of battery strings $=15$.

Total watt hour $=(48 \times 200 \times 15)=144,000$. 


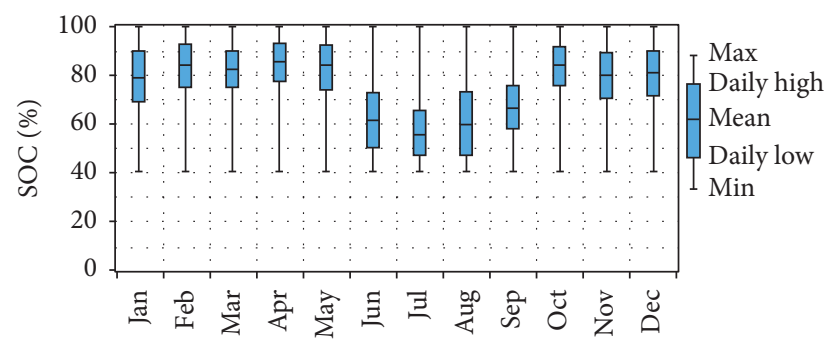

FIgURE 8: Monthly statistics.

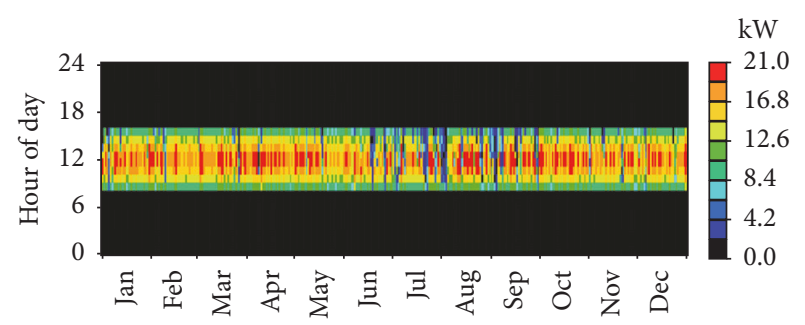

FIGURE 9: Inverter output.

Total volume of water needed to be stored in the water $\operatorname{tank}$,

$$
\begin{aligned}
m(\mathrm{~kg}) & =\frac{144000 \times 3600}{17.15 \times 9.81} \\
& =3.081 \times 10^{6} \mathrm{~kg} \text { or } 3081 \mathrm{~m}^{3}
\end{aligned}
$$

To store $3.081 \times 10^{6} \mathrm{~kg}$ or about $3081 \mathrm{~m}^{3}$ of water, we need at least 3081 cubic meters or 3100 cubic meter water tank. As The height of the tank is already decided, either we need to build a large rectangular tank $(40 \mathrm{~m} \times 26 \mathrm{~m} \times 3 \mathrm{~m})$ or a cylindrical tank of around $18 \mathrm{~m}$ radius.

\section{Dynamic Simulation}

Dynamic model for solar irrigation pumping system for both battery-based and battery-less systems was built in MATLAB Simulink. Both models were simulated for same input data of irradiance and temperature.

6.1. Battery-Less System. In the battery-less system, a boost converter was used to increase the voltage level from $48 \mathrm{~V}$ to $460 \mathrm{~V}$ to run the induction motor to lift ground water. A three-level bridge converter was used as inverter to convert the DC component into AC component. This system consists of a large water tank which can store around $3100 \mathrm{~m}^{3}$ of water and a limited integrator was used to indicate the tank water level. $38.4 \mathrm{kWp}$ solar array provided the energy needed to run the model. Figure 11 demonstrates the dynamic model of a battery-less solar irrigation pumping system.

6.2. Battery-Base System. Figure 12 shows the dynamic model of a battery-based solar irrigation pumping system. A MPPT trucker was used here to operate the system at maximum power point. A two-level bridge was used to convert the DC component into AC component. A three-phase transformer

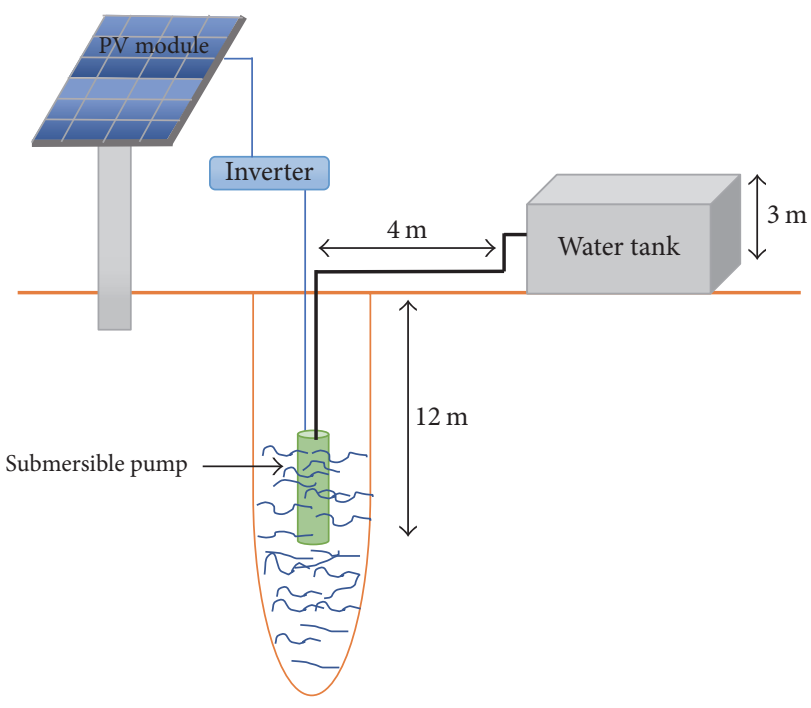

FIGURE 10: Block diagram of the water tank storage system.

was used instead of a boost converter to increase the voltage level to run the motor. A large battery bank of capacity 3000 Ahr was used to store energy for further use. In this system, the same water tank (as in battery-less system) was kept to measure the volume of extracted water.

\section{Result and Analysis}

7.1. Sensitivity Analysis. Sensitivity analysis of solar irrigation pumping system was carried out during HOMER optimization with $10 \%$ variation in load $(119 \mathrm{~kW} / \mathrm{d}, 107 \mathrm{kWh} / \mathrm{d}$, and $131 \mathrm{kWh} / \mathrm{d})$ and irradiance $\left(4.52 \mathrm{kWh} / \mathrm{m}^{2} / \mathrm{d}, 4.07 \mathrm{kWh} / \mathrm{m}^{2} / \mathrm{d}\right.$, and $4.99 \mathrm{kWh} / \mathrm{m}^{2} / \mathrm{d}$ ). Figure 13(a) demonstrates how the total NPC (Net Present Cost) fluctuates with the variation of irradiance and load. For lowest and highest load demand, the total NPC decreases linearly with the increase of irradiance. In case of $119 \mathrm{kWh} / \mathrm{d}$ load demand, the NPC falls sharply as irradiance goes higher.

However, the Cost of Energy (COE) is the same for any voltage demand at highest irradiance level as in Figure 13(b). However, for lowest irradiance level, the COE is the same for $119 \mathrm{kWh} / \mathrm{d}$ and $131 \mathrm{kWh} / \mathrm{d}$. The COE of lowest and average load demand become the same when the solar PV modules get average irradiance.

Figure 13(c) shows the similar relationship to Figure 13(a). Operating costs are almost similar for lowest and average load demand at average irradiance. For average load demand, there is a hike in operational cost at lowest irradiance, but it is not true for $107 \mathrm{kWh} / \mathrm{d}$ load demand.

7.2. Simulation Result Analysis. Simulation was done for both dynamic models in MATLAB Simulink. For battery-based system, simulation was done for two seconds and five seconds for battery-less system (each simulation required many hours of computer operation).

7.2.1. Battery-Less System. PV module voltage and current at maximum power point are $35.8 \mathrm{~V}$ and $8.68 \mathrm{~A}$ accordingly. As 

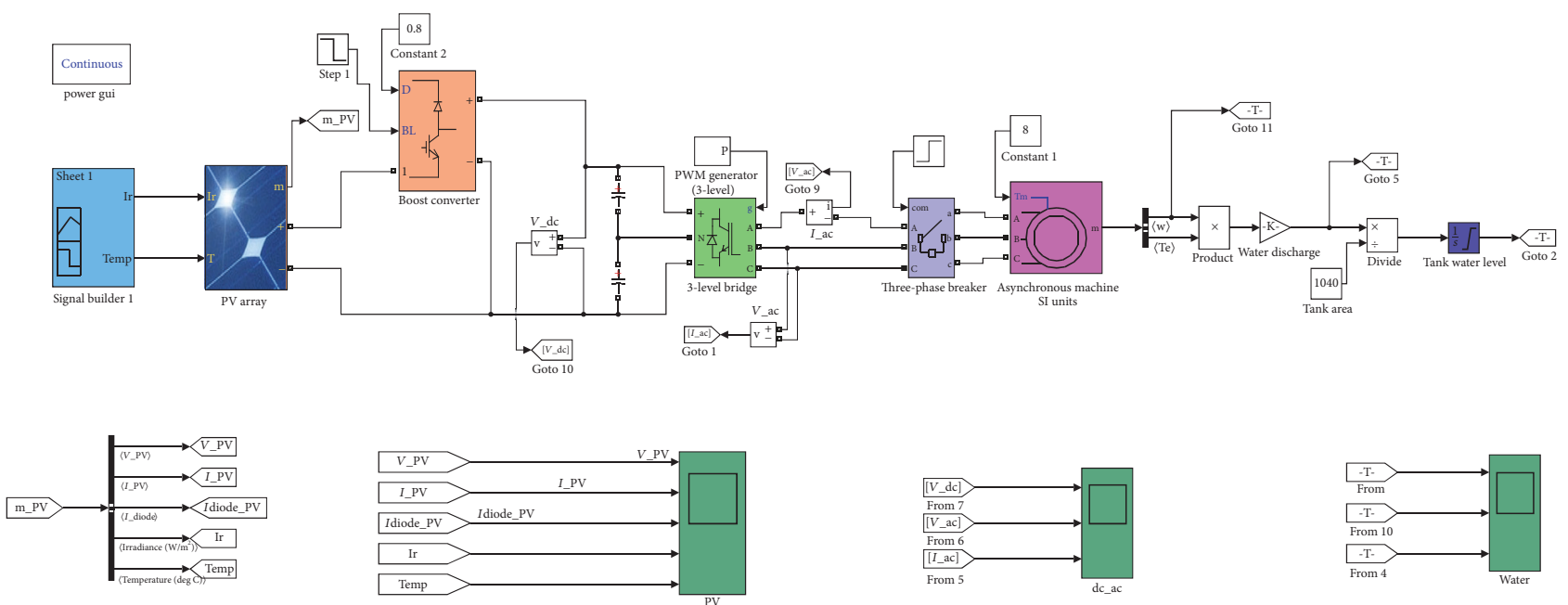

FIGURE 11: Dynamic modelling of battery-less system.

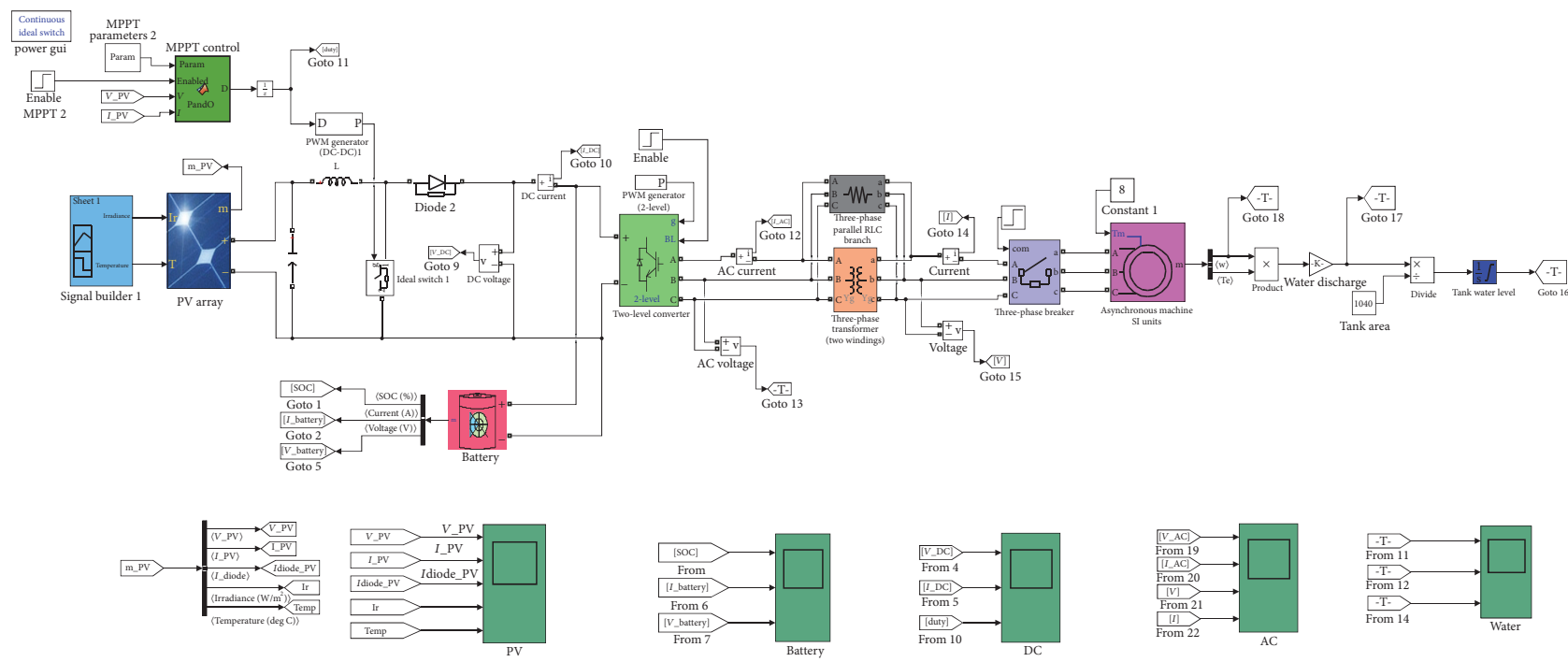

FIGURE 12: Battery-base system.

the selected panel is 72 cell panels and two is the number of panels connected in series per string, the bus voltage should be $48 \mathrm{~V}$. Total number of strings is 62 . Figure 14 shows the irradiance, temperature, diode current, PV voltage, and PV current.

Boost converter increased the voltage PV voltage level. $V \_$dc denotes the boosted-up dc voltage in Figure 15. I_ac and $V_{-}$ac indicate the converted ac current and voltage accordingly.

Figure 16(a) demonstrates the rotor speed ( $\mathrm{rad} / \mathrm{sec})$. The motor is running at full load and the rotor speed becomes $187 \mathrm{rad} / \mathrm{s}$ or 1785.72 r.p.m which was expected.

Figure 16(b) shows the water discharge $\left(\mathrm{m}^{3} / \mathrm{s}\right)$ and tank water level $(\mathrm{m})$. The average water discharge during five seconds of simulation was $0.05 \mathrm{~m}^{3} / \mathrm{s}$ or $180 \mathrm{~m}^{3} / \mathrm{h}$. If the system runs for eight hours, the induction motor will be able to lift $1440 \mathrm{~m}^{3}$ of water per day, which is close to the estimated value. During the first five seconds, the water level in the large water tank $(40 \mathrm{~m} \times 26 \mathrm{~m} \times 3 \mathrm{~m})$ reached $1.74 e^{-4} \mathrm{~m}$. After eight hours of operation, the tank water level would reach at least $1 \mathrm{~m}$ and volume of lifter water per day would be $1040 \mathrm{~m}^{3}$.

7.2.2. Battery-Based System. The number of strings in PV module remains the same for battery-based system; else a small transformer and a MPPT (Maximum Power Point Tracker) are used here instead of a boost voltage. Figure 17 shows the irradiance, temperature, diode current, PV voltage, and PV current.

Figure 18 shows DC voltage, DC current, and duty cycle of the MPPT tracker. The voltage was $48 \mathrm{~V}$ as expected. The value duty cycle was 0.45 .

The battery voltage, current, and state of charge are demonstrated in Figure 19. Battery state of charge remains at 


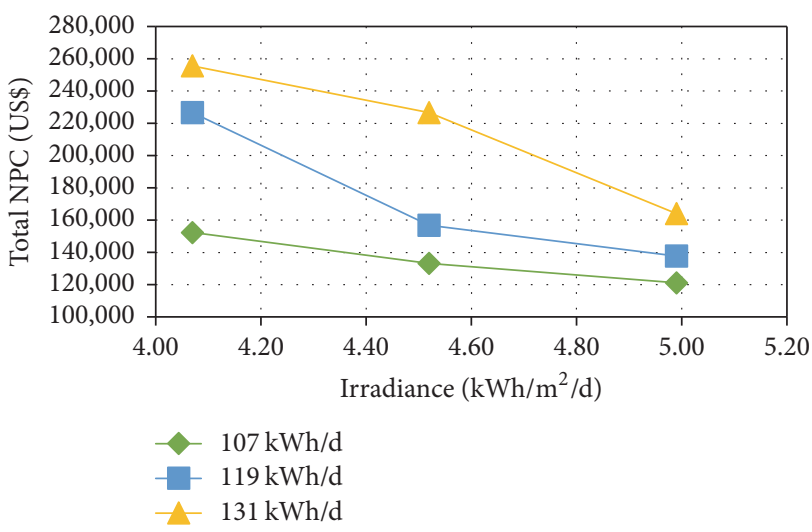

(a)

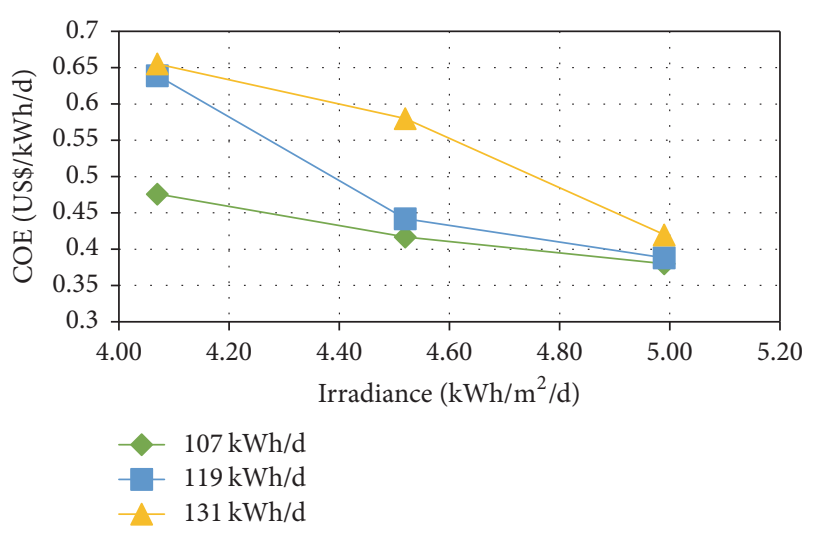

(b)

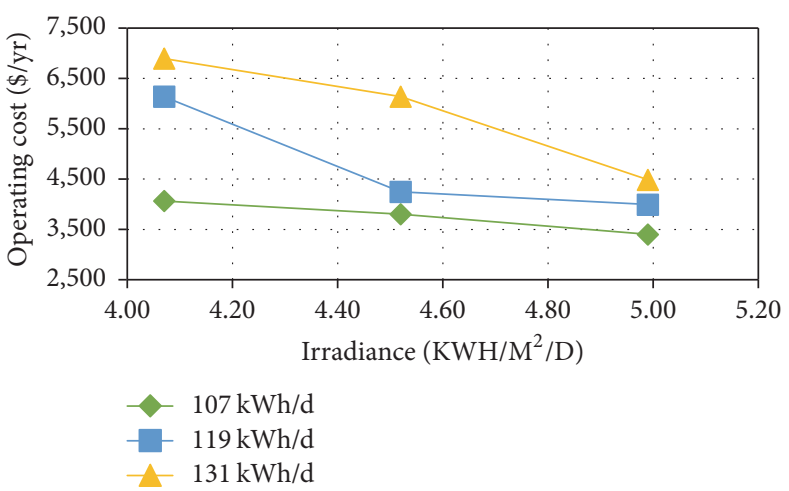

(c)

FIGURE 13: (a) Sensitivity analysis based on NPC; (b) sensitivity analysis based on COE; (c) sensitivity analysis based on operating cost.

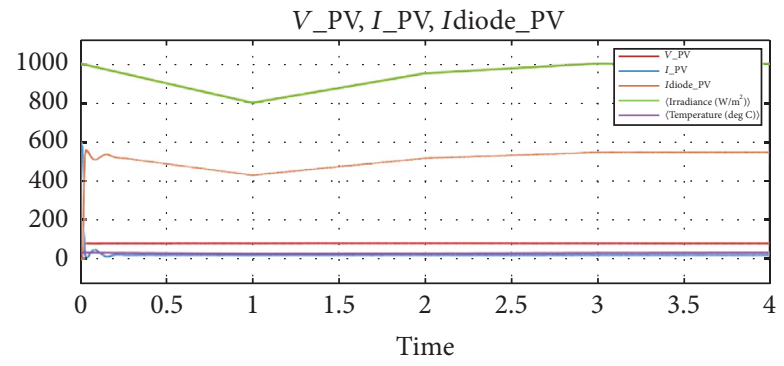

FIGURE 14: PV module components.

$60 \%$ (initial state of charge was decided as $60 \%$ ) as the model was run for only two seconds. As the battery was discharging, the direction of current was negative. Battery voltage was the same as nominal voltage $(48 \mathrm{~V})$.

The inverted AC voltage and current are denoted by AC voltage and AC current in Figure 20 which are output voltage and current. The transformer secondary current and voltage are denoted by current and voltage accordingly.

The rotor speed of induction motor was $186 \mathrm{rad} / \mathrm{s}$ or 1776.17 r.p.m, similar as battery-less system shown in Figure 21(a). Figure 21(b) demonstrates the water discharge $\left(\mathrm{m}^{3} /\right.$ $\mathrm{s})$ and tank water level (m). Water discharge was also the same as battery-less system, $0.05 \mathrm{~m}^{3} / \mathrm{s}$ or $180 \mathrm{~m}^{3} / \mathrm{h}$. In case of battery-based system, the water tank size was kept similar

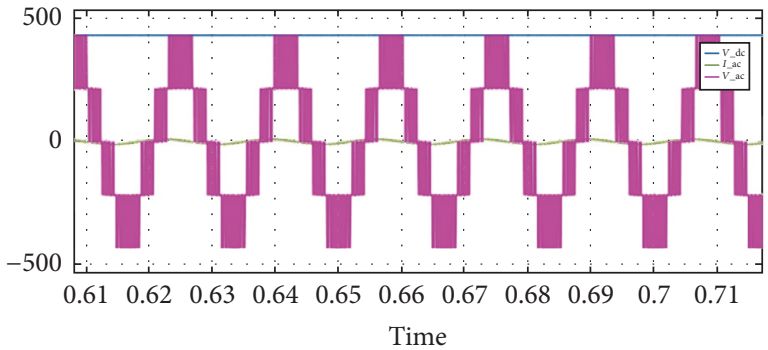

FIGURE 15: AC and DC voltage and current.

$(40 \mathrm{~m} \times 26 \mathrm{~m} \times 3 \mathrm{~m})$ to measure the volume of total amount of lifted water.

During the first two seconds of simulation, the tank water level reached $4.24 e^{-5} \mathrm{~m}$. After eight hours of operation, the tank water level would reach at least $0.61 \mathrm{~m}$ and volume of lifter water per day would be $634.4 \mathrm{~m}^{3}$. The excess energy would be stored as electrical form in battery storage.

\section{Effectiveness Analysis}

Effectiveness of the alternative systems was compared from economic point of view. The project lifetime was decided as 25 years. The economic comparison was done among four alternatives: battery-less system, battery-based system, 


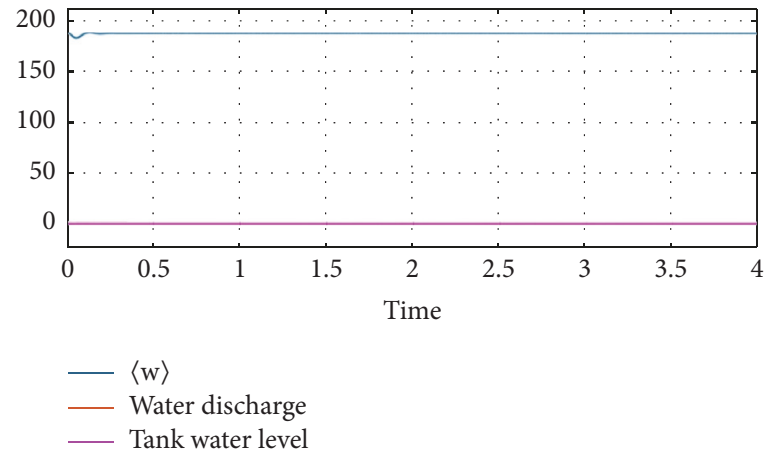

(a)

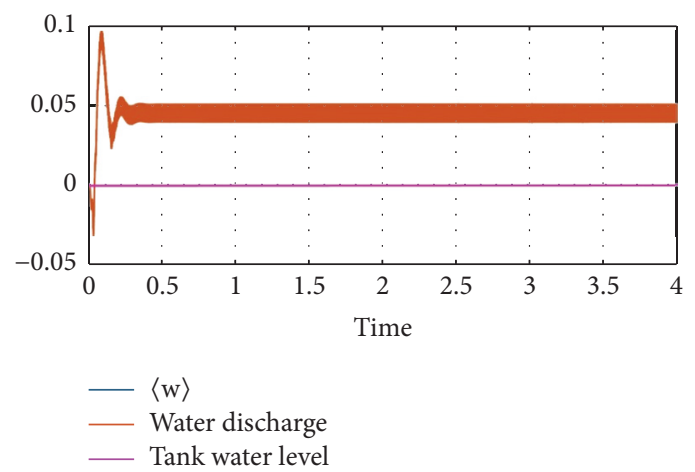

(b)

FIGURE 16: (a) Rotor speed; (b) water discharge and tank water level.

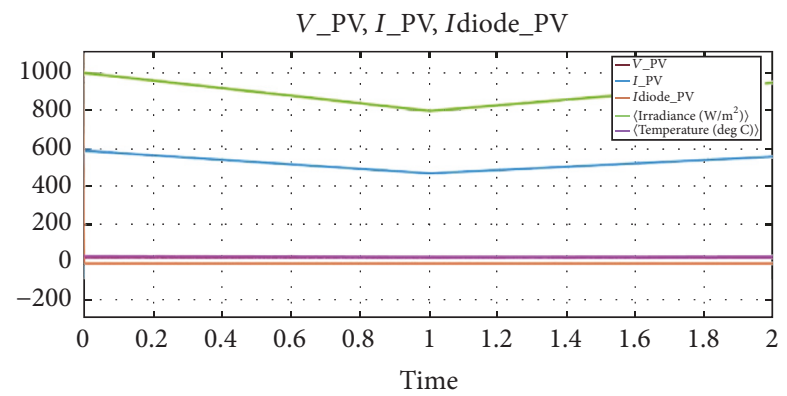

FIgURE 17: PV module components.

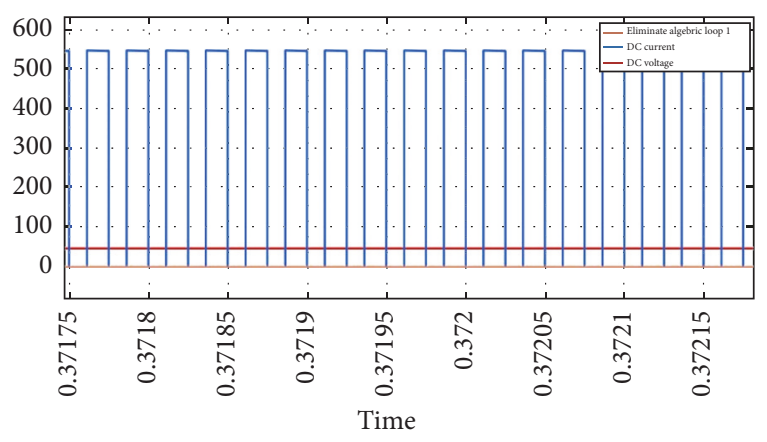

Figure 18: DC components.

combination of both, and diesel engine system based on total cost. All categories were simulated in HOMER to obtain the most feasible solution of each group. Present market price (US\$) of each component of each group was selected separately as the system elements are different from each other.

Figure 22(a) shows the total cost at the very beginning of the project (first year) while Figure 22(b) demonstrated the total cost of the project for twenty-five years of operational period.

Total cost of the diesel engine system is lowest for oneyear operational period, but it is the worst solution for longer period. Moreover, diesel operated engine will cause pollution to the environment. Table 3 gives an idea about the emission of diesel operated system.

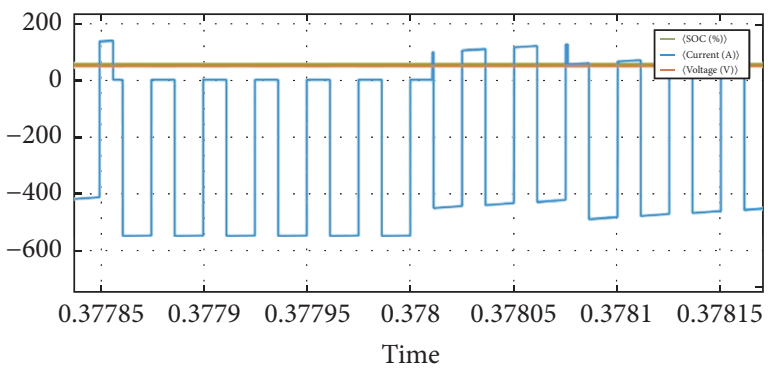

FIGURE 19: Battery storage.

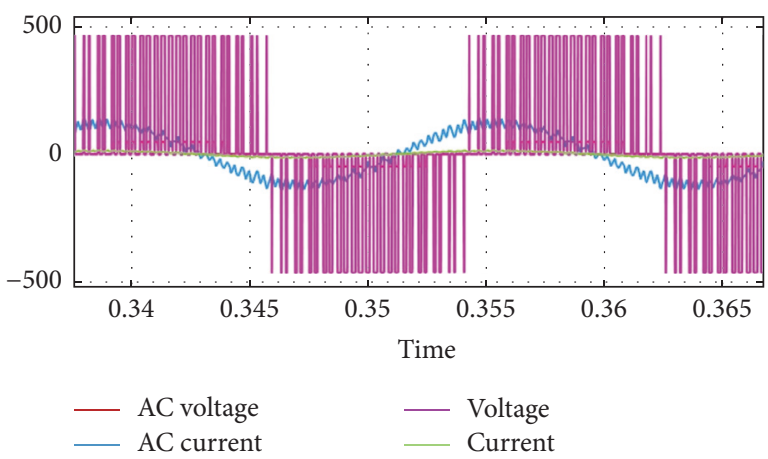

FIGURE 20: System output voltage and current.

TABLE 3: Emission.

\begin{tabular}{lc}
\hline Pollutant & Emission $(\mathrm{kg} / \mathrm{yr})$ \\
\hline Carbon dioxide & 44,566 \\
Carbon monoxide & 110 \\
Unburned hydrocarbons & 12.2 \\
Particulate matter & 8.29 \\
Sulfur dioxide & 89.5 \\
Nitrogen oxides & 982 \\
\hline
\end{tabular}

Although the cost difference between the battery-less and battery-based system is higher on first year of the project, the difference decreases strongly for a period of 25 years because there is no replacement cost for water tank. The replacement 


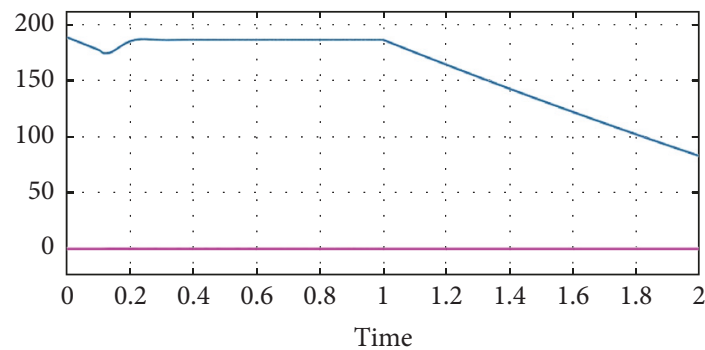

$\langle\mathrm{w}\rangle$
_ Water discharge
Tank water level

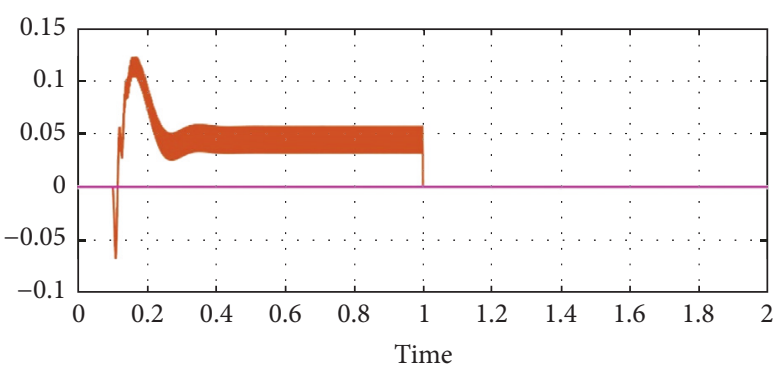

$\langle w\rangle$

- Water discharge

_ Tank water level

(a)

(b)

FIGURE 21: (a) Rotor speed; (b) water discharge and tank water level.

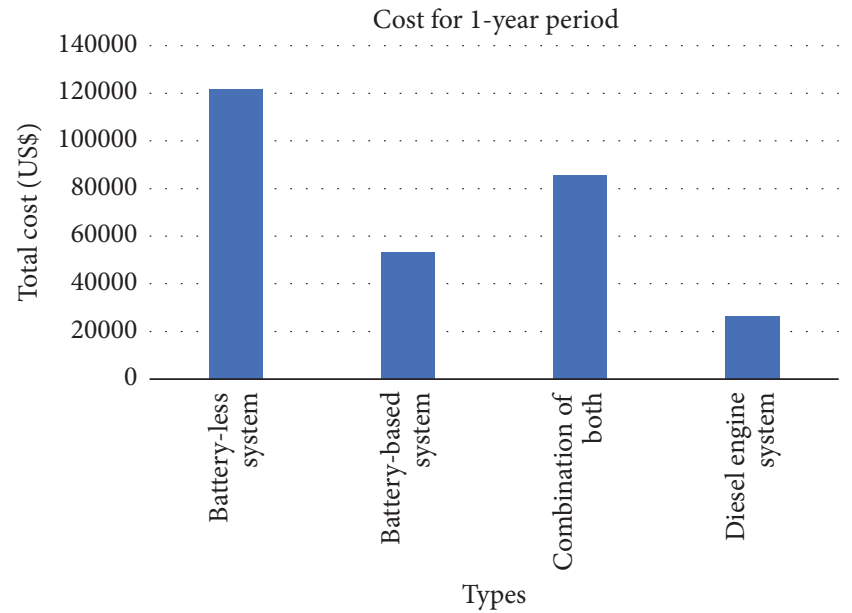

(a)

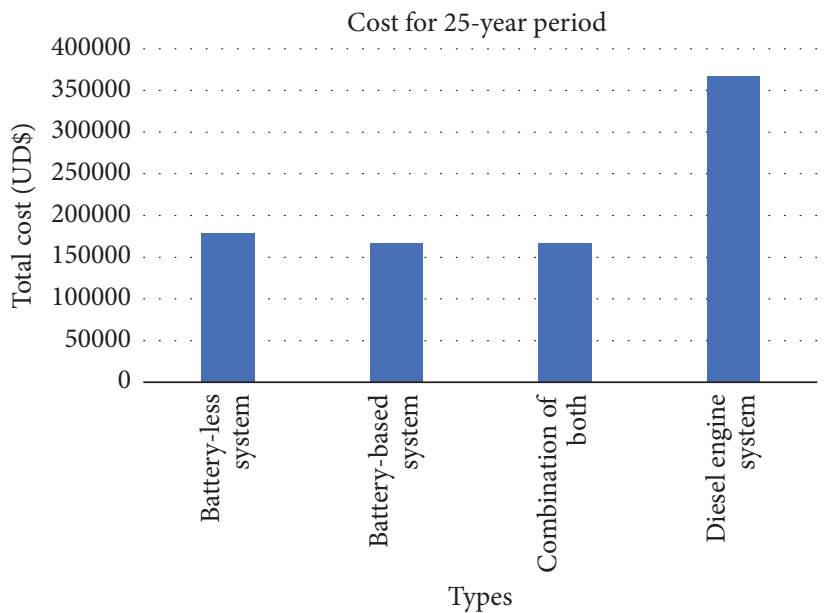

(b)

Figure 22: (a) System cost for one-year period; (b) system cost for twenty-five year period.

cost of battery storage needs to be considered. Combination of both consists of a smaller water tank, half of the tank size used in battery-less system and a battery storage of 1400 Ahr. Total cost of this combination lies between the cost of battery-less and battery-based system at the very beginning, but it becomes the cheapest solution for 25 years of period. Combination of both storage systems is the reasonable solution because it can store energy in electrical form and store some water for any emergency.

\section{Discussion}

The main objective of this paper was to develop dynamic models for both battery-less and battery-based system to run a motor-pump set using solar energy to lift ground water for irrigation purpose. Sizing was done for battery-based system in HOMER which was also validated using hand calculation. Water tank equivalent battery storage was also calculated for battery-less system. Two different dynamic models were built in MATLAB Simulink to demonstrate the battery-less and battery-based system. Simulation was done for a very short time: 5 seconds for battery-less system and 2 seconds for battery-based system since a longer duration needed many days of computer time. The rotor speed was $187 \mathrm{rad} / \mathrm{s}$ (1785.72 r.p.m) for battery-less system and $186 \mathrm{rad} / \mathrm{s}$ (1776.17 r.p.m) for battery-based system which matched the expected results. The water discharge rate for both systems was $0.05 \mathrm{~m}^{3} / \mathrm{s}$ or $180 \mathrm{~m}^{3} / \mathrm{h}$. After eight hours of operation, the stored water fills only one-third volume of the large water tank. The dynamic simulation and sizing estimation using HOMER encouraged going with the combination of battery storage and water storage system. Economic analysis based on total cost was done for all alternatives: battery-less system, battery-based system, combination of both, and diesel engine system. The analysis was done for two different time periods: first year of installation (one year) and twenty-five years of operational period. For longer operational period, diesel operated engine is the costliest solution and the combined storage system is the most economical solution. Feasibility analysis from economic point of view helped in finding out 
the reasonable solution among four alternatives. Sensitivity analysis shows the variation of total NPC, COE, and operating cost with the variation of $\pm 10 \%$ load and irradiance. For lowest load demand, costs (NPC, COE, and operational cost) and irradiance have negative relationship. Total NPC, COE, and operating costs show hike at lowest irradiance in case of average load demand. All costs are always higher for highest load demand.

\section{Conclusions}

Renewable energy system offers an alternative way for sustainable development of a country. This project indicates that the solar water pumping system can be integrated to irrigation systems in Bangladesh as it is feasible solution for longer period. For twenty-five years of life cycle, solar PV system will cost half of the diesel engine operated system. Combination of both battery storage and water tank is the economically feasible solution to meet the irrigation challenges faced during dry season.

\section{Conflicts of Interest}

The authors declare that there are no conflicts of interest regarding the publication of this paper.

\section{Acknowledgments}

The authors would like to acknowledge NSERC and MUNSGS for providing funding for this research. The authors also thank Sherpa Power Engineering Limited for providing the site data for analysis.

\section{References}

[1] Bangladesh bureau of Statistics (BBS), "Yearbook of agricultural Statistics," 2015.

[2] S. I. Khan, M. M. Sarkar, and M. Q. Islam, "Design and analysis of a low cost solar water pump for irrigation in bangladesh," Journal of Mechanical Engineering, vol. 43, no. 2, 2014.

[3] Bangladesh Agricultural Development Corporation (BADC), Shech Bhavan, and Dhaka, "Summary of irrigation equipment used, area irrigated and benefited farmers:2010-2011," 2012.

[4] H. Biswas and F. Hossain, "Solar Pump: A Possible Solution of Irrigation and Electric Power Crisis of Bangladesh," International Journal of Computer Applications, vol. 62, no. 16, pp. 1-5, 2013.

[5] M. A. Hossain, M. S. Hassan, M. A. Mottalib, and M. Hossain, "Feasibility of solar pump for sustainable irrigation in Bangladesh," International Journal of Energy and Environmental Engineering, vol. 6, no. 2, pp. 147-155, 2015.

[6] M. Abu-Aligah, "Design of photovoltaic water pumping system and compare it with diesel powered pump," Jordan Journal of Mechanical and Industrial Engineering, vol. 5, no. 3, pp. 273-280, 2011.

[7] M. Arrouf and S. Ghabrour, "Modelling and simulation of a pumping system fed by photovoltaic generator within the Matlab/Simulink programming environment," Desalination, vol. 209, no. 1-3, pp. 23-30, 2007.
[8] S. G. Malla, C. N. Bhende, and S. Mishra, "Photovoltaic based water pumping system," in Proceedings of the 2011 International Conference on Energy, Automation and Signal, ICEAS - 2011, pp. 448-451, India, December 2011.

[9] C. Gopal, M. Mohanraj, P. Chandramohan, and P. Chandrasekar, "Renewable energy source water pumping systems A literature review," Renewable \& Sustainable Energy Reviews, vol. 25, pp. 351-370, 2013.

[10] F. Loxsom and P. Durongkaveroj, "Estimating the performance of a photovoltaic pumping system," Solar Energy, vol. 52, no. 2, pp. 215-219, 1994.

[11] F. Cuadros, F. López-Rodríguez, A. Marcos, and J. Coello, "A procedure to size solar-powered irrigation (photoirrigation) schemes," Solar Energy, vol. 76, no. 4, pp. 465-473, 2004.

[12] Z. Glasnovic and J. Margeta, "A model for optimal sizing of photovoltaic irrigation water pumping systems," Solar Energy, vol. 81, no. 7, pp. 904-916, 2007.

[13] H. E. Gad, "Performance prediction of a proposed photovoltaic water pumping system at South Sinai, Egypt climate conditions in," in Proceedings of the thirteenth international water technology conference, pp. 739-752, Hurghada, Egypt, 2009.

[14] S. Harishankar, R. Satish Kumar, U. Vingesh, and T. Viveknath, "Solar powered smart irrigation system," Advance in Electronic and Electric Engineering, vol. 4, no. 4, pp. 341-346, 2014.

[15] W. R. Anis and M. A. Nour, "Optimum design of a photovoltaic powered pumping system," Journal of Power Sources, vol. 50, no. 1-2, pp. 1-9, 1994.

[16] S. S. Chandel, M. Nagaraju Naik, and R. Chandel, "Review of solar photovoltaic water pumping system technology for irrigation and community drinking water supplies," Renewable \& Sustainable Energy Reviews, vol. 49, article no. 4338, pp. 10841099, 2015.

[17] N. Argaw, "Optimisation of photovoltaic water pumps coupled with an interfacing pulse width modulated DC/AC inverter power conditioning device," in Proceedings of the 1994 IEEE 1st World Conference on Photovoltaic Energy Conversion - WCPEC, pp. 1165-1168, Waikoloa, Hawaii, USA, 1994.

[18] P. C. Pande, A. K. Singh, S. Ansari, S. K. Vyas, and B. K. Dave, "Design development and testing of a solar PV pump based drip system for orchards," Journal of Renewable Energy, vol. 28, no. 3, pp. 385-396, 2003.

[19] M. Benghanem, K. O. Daffallah, A. A. Joraid, S. N. Alamri, and A. Jaber, "Energy Conversion and Management," Science Direct, vol. 65 , pp. 50-56, 2013.

[20] R. Senol, "An analysis of solar energy and irrigation systems in Turkey," Energy Policy, vol. 47, pp. 478-486, 2012.

[21] Md. Abul Hasnat, M. N. Hasan, and N. Hoque, "A brief study of the prospect of hybrid solar irrigation system in Bangladesh," in Proceedings of the International Conference on Mechanical and Energy Engineering, 2014.

[22] M. M. Hoque, "Photovoltaic water pumping system for irrigation," in Proceedings of the 4th International Conference on Mechanical Engineering, Dhaka, Bangladesh, 2001.

[23] A. Hamidat and B. Benyoucef, "Mathematic models of photovoltaic motor-pump systems," Journal of Renewable Energy, vol. 33, no. 5, pp. 933-942, 2008.

[24] A. Mokeddem, A. Midoun, D. Kadri, S. Hiadsi, and I. A. Raja, "Performance of a directly-coupled PV water pumping system," Energy Conversion and Management, vol. 52, no. 10, pp. 30893095, 2011. 
[25] R. E. Katan, V. G. Agelidis, and C. V. Nayar, "Performance analysis of a solar water pumping system," in Proceedings of the 1996 International Conference on Power Electronics, Drives \& Energy Systems for Industrial Growth, PEDES'96. Part 1 (of 2), pp. 81-87, January 1996.

[26] M. T. A. Khan, M. R. Ahmed, S. I. Ahmed, and S. I. Khan, "Design and performance analysis of water pumping using solar PV," in Proceedings of the 2nd International Conference on the Developments in Renewable Energy Technology, ICDRET 2012, pp. 48-51, bgd, January 2012. 

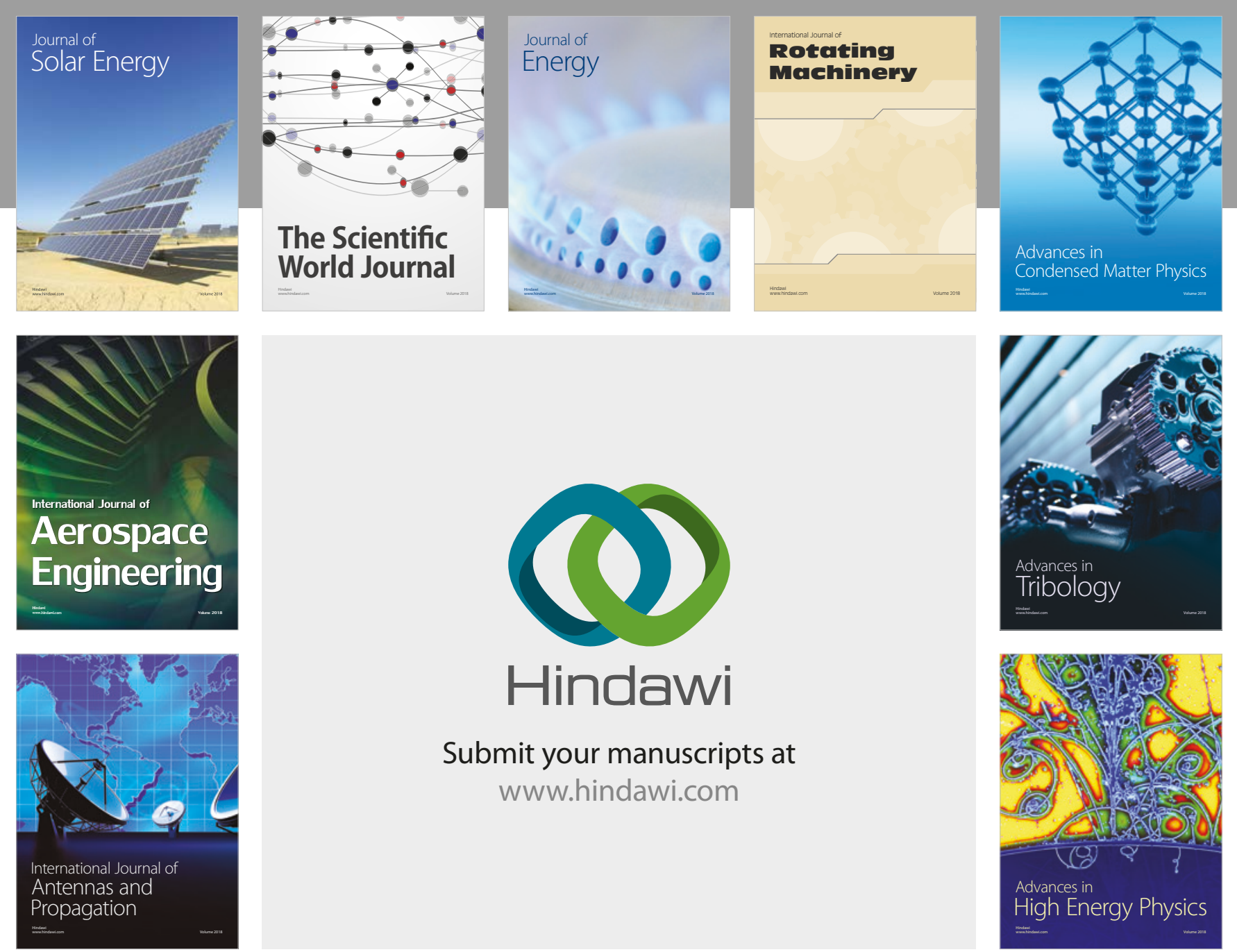

Submit your manuscripts at

www.hindawi.com
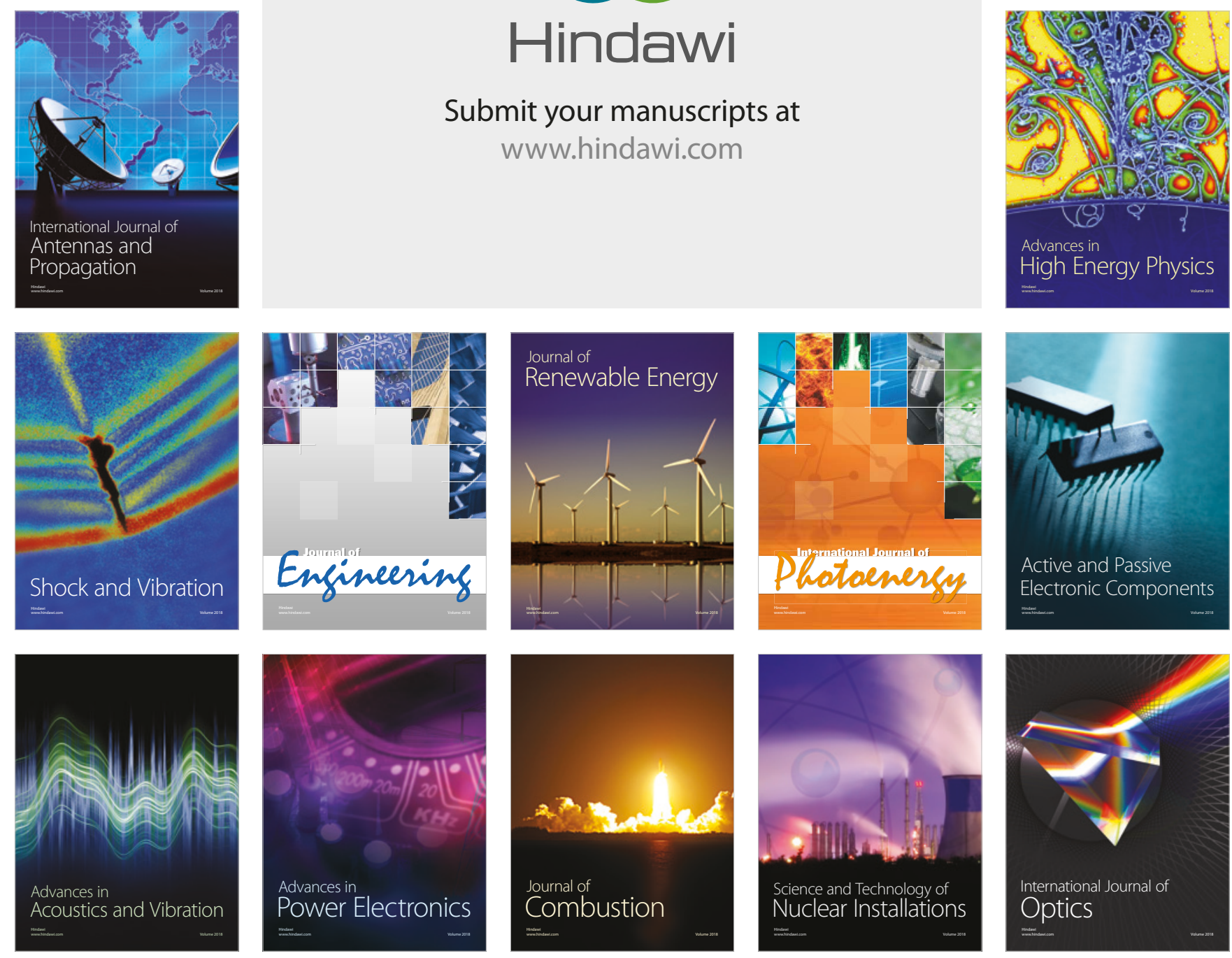